destined to enjoy each other's society, as Mr. CAмомILE drives one about all day and rides the other round the conntry all night. Now at the end of the year, with all his riding and all his pill-rolling, the unfortunate practitioner just manages to make both ends meet; for the time has come when little JoHNNy must go to school to be initiated in the niceties of Roman versification, with a view to making his way in the world at a subsequent period. The eldest daughter, Anna Maria, too, must be gently led in the direction of Cramer's exercises, and be instructed in the art of hemming pocket-handkerchiefs. Poor Camomile, who was born with a kindly, genial soul, cannot but entertain the local dining club once a year at Opodeldoc Lodge, when the planned furniture of the dining and drawing rooms is divested of its brown-holland epidermis, and even the tissue paper which had been pinned round the broad gilt frame of Mrs. CAMomile's portrait, for fear of fly-blows, is removed for that night only. The expense of that entertainment, which exactly equals CA MomiLE's overpayment to the Incometax, is probably the only expense throughout the year which will not bear the strictest investigation, but it helps, with his necessary outlays, to pull him down. The life, no doubt, is a hard one-a harder one than great politicians woula readily imagine; but still, while health lasts, it is tolerable, and not without its compensation, to a man of honest and humane temperament. But the night comes, when poor Camomile, - who has been roused from his sleep to assist at a premature birth, at some seven or eight miles distance from his own house, rides there through the pelting rain, and sits during the anxious night by the bed-side of his suffering patient in his wet clothes. A cough follows; he cuts off his dinner, but continues his rides; his symptoms become aggravated by exposure to the weather, and in a fortnight he is beyond the reach of his own skill, and in a fortnight and a day beyond saving by any physician upon earth. He goes where we all must go; but Mrs. CAMOMile, and JohNNy, and Anna Maria, awake from their dream of security to find that their means of support have gone as well. They must content themselves with being -as political economists would phrase it-absorbed into the population. That is to say, when the two horses and the planned and other furniture, and the house, and the galley-pots are sold up, there is just enough to clear scores all round, and pay for the only spot of earth in which CAmomile had known the peaceful rest of an hour since the day he first established himself at Opodeldoc Lodge. Why did he not insure his life for a few hundred pounds ? will be the comment of many a strongminded person upon this faint outline of a life. Simply because it pleased the Finance Minister of his country for the time being playfully to suppose that his income would inure to his children after him, and to mulct him accordingly. To be sure he might have dropped his annual entertainment to the members of the Hawthorn Dining Club-but then some of us come from one side the Tweed, some from the other."

\section{EPIDEMIOLOGICAL SOCIETY.}

The third ordinary meeting of this Society was held on Monday, February 3rd, in the rooms of the Royal Medical and Chirurgical Society. Dr. Babington, the president in the chair. Seven members, nine corresponding, and one honorary member were admitted, and seven new candidates for membership were proposed.

A paper by Dr. Hoskins, "On the Origin and Progress of Cholera and Small Pox in Guernsey," was read by Dr. Gull. The facts recorded by Dr. Hoskins were highly interesting, for the most part adverse to the doctrine of contagion.

Mr. Grainger said that if a widely extended view were taken of the history of cholera, he thought that the diffusion of the disease appeared to be effected rather $<$ by places than by persons, and that the proof of its communicability from one person to another would be $\varrho$ found insufficient.

Mr. Hunt admitted that at certain times, and in certain places, the disease did not appear to be contagious, but he believed that on other occasions it was clearly to. be traced from person to person. He, therefore, was $\overrightarrow{7}$ inclined to think that, like erysipelas, puerperal fever, $\stackrel{\text { ? }}{+}$ and other diseases, it varied in its type, being some-O times contagious at other times not so.

Dr. James Bird said that he had seen much of the disease in India; that, in a certain sense, it was never contagious, and never thought to be contagious in that $\stackrel{\mathbb{Q}}{\varrho}$ country; but that where the diseased were congregated 0 together a degree of infection was generated; and that ${ }^{\infty}$ when it broke out among troops, many sleeping in the $\vec{\circ}$ same apartments, its spread was soon arrested by the men being ordered into separate tents.

Dr. Gull said, that if the disease were generated by the diffusion of putrid gases, he did not see how it could ever become contagious. On the other hand, if 3 . the germs of the disease were transmitted in a solid is form from person to person, a condition in some sense ? necessary to contagion, it was difficult to conceive that $\vec{G}$ atmospheric influence alone should promote the disease.

The paper announced to be read at the next meeting in March, is "On the Yellow Fever which has lately $\vec{N}$ appeared in the Brazils."

The President announced that the Treasurer had 음 received a cheque for five guineas from David Fullarton, $\overrightarrow{0}$ Esq., of Kidbrooke Park, Forest Row, Kent, as a con- 0 tribution toward the funds of the Society; and expressed $T$ a hope that so good an example would be followedo by many others.



APPOINTMENTS

Mr. W. W. James has been elected one of the $S$ geons to the Exeter Dispensary, in the room of W. P. Kingdon, resigned; and $\mathrm{Mr}$. W. P. Kingdono has been elected Consulting-Surgeon to the same Insti-tution.

\section{ROYAL COLLEGE OF SURGEONS.}

The following gentlemen were admitted members on Friday, the 7th inst. :-William Paul Bullock. Bristol; Edward Connor Cornelius, Upper Canada Charles Manteiro D'Almeida Lempriere, Australia Duncan MacCallum, Montreal, Canada; Frederic Francis Ormond, Plymouth; Philip Henry Tribe Bengal; Watkin Sandon Whyloch, Chatham.

\section{SOCIETY OF APOTHECARIES}

The following gentlemen ware admitted members on Thursday, Feb. 6th:-Francis Thomas Van Hemert, Frodingham, Lincolnshire; William Lay Williams, Manchester.

\section{OBITUARY.}

On the 8th inst., at Hastings, James Mackness, M.D․ㅡㄹ.

Erratum.-In Mr. Bree's “ Protest," January $22 \mathrm{\omega}$ page 55, col. 1, second paragraph, for " unfair" reaf "inferior" College.

TO CORRESPONDENTS.

Communications have been received from Dr. Nelson Mr. Hatton, Dr. Tilt, and Dr. Durrant.

A Frequent Reader must authenticate his communica tion prior to its insertion. 